\title{
MISMATCH NEGATIVITY AND THE N2B COMPONENT ELICITED BY PURE TONES AND SPEECH SOUNDS IN ANOMIC APHASIA: A CASE STUDY
}

\author{
David Tome ${ }^{1,2}$, Brigida F. Patricio3, Vinaya Manchaiah ${ }^{4,5,6}$, Fernando Barbosa ${ }^{1}$, \\ Joao Marques-Teixeira ${ }^{1}$
}

${ }^{1}$ Faculty of Psychology and Educational Sciences, Laboratory of Neuropsychophysiology, University of Porto, Porto, Portugal

${ }^{2}$ Department of Audiology, School of Allied Health Technologies, Polytechnic Institute of Porto, Porto, Portugal

${ }^{3}$ Department of Speech Therapy, School of Allied Health Technologies, Polytechnic Institute of Porto, Porto,

Portugal

${ }^{4}$ Department of Speech and Hearing Sciences, Lamar University, Beaumont, TX, USA

${ }^{5}$ Linnaeus Centre Hearing and Deafness, Swedish Institute for Disability Research, Linköping University,

Linköping, Sweden

${ }^{6}$ Audiology India, Mysore, India

Corresponding author: David Tome, Faculty of Psychology and Educational Sciences, Laboratory of

Neuropsychophysiology, University of Porto, Porto, Portugal, e-mail: dts@estsp.ipp.pt

\begin{abstract}
Background: The auditory processing impairments frequently observed in aphasia are being slowly clarified by using eventrelated potentials (ERPs), a method that allows brain processes to be observed at high temporal resolution. Mismatch negativity (MMN) and the $\mathrm{N} 2 \mathrm{~b}$ amplitude reflect aspects of echoic memory, attention, and phonological representation. This study evaluates the auditory processing of speech and pure tones in an anomic aphasia subject 6 years after a stroke, and investigates whether ERPs can detect possible neurophysiologic sequelae after recovery and rehabilitation.
\end{abstract}

Material and methods: A recovered subject with anomic aphasia, 6 years post-stroke, was compared with 6 healthy controls. Event-related potentials (MMN, N1, N2b) were obtained during two auditory oddball paradigms, one using pure tones and the other consonant-vowel $(\mathrm{CV})$ stimuli.

Results: When compared to healthy subjects, the anomic aphasia subject had reduced MMN amplitude across the frontocentral electrode sites, particularly for speech stimuli. Average deviant waveform analysis revealed poor morphology of N2b to speech stimuli, which might relate to deficits in phonological representation.

Conclusions: In the presented case the neurophysiologic brain activity for processing of phonologic representations had not fully recovered 6 years post-stroke. MMN and N2b are highly sensitive ERPs for evaluating impairments in auditory processing and can be registered in the absence of attention and with no task requirements, features which makes it particularly suitable for investigating aphasic subjects.

Keywords: mismatch negativity $(\mathrm{MMN}) \bullet \mathrm{N} 2 \mathrm{~b} \bullet$ anomic aphasia $\bullet$ auditory processing

\section{EL POTENCIAL DE DISPARIDAD Y EL COMPONENTE N2B CAUSADOS POR} SONIDOS TONALES Y EL HABLA EN PERSONAS CON DISNOMIA: ESTUDIO DE CASO

\section{Resumen}

Introducción: La explicación de los trastornos observados a menudo de procesamiento auditivo se realiza por el uso de potenciales evocados (ERP), un método que permite observar los procesos cerebrales con alta resolución temporal. El potencial de disparidad o mismatch negativity (MMN) y la amplitud del componente N2b reflejan los aspectos de la memoria onomatopéyica, de la concentración de la atención y la representación fonológica. En el presente trabajo se ha evaluado el procesamiento del habla auditivo y de sonidos tonales en personas con disnomia a los 6 años de la ictus y se ha buscado una respuesta a la pregunta si los potenciales evocados pueden ayudar a encontrar posibles consecuencias neurofisiológicas después de reponerse o una rehabilitación.

Materiales y métodos: Los resultados de una persona con disnomia que hace 6 años tuvo ictus y después fue sometida a una terapia fueron comparados con los resultados de 6 personas sanas. Para conseguir potenciales evocados (MMN, N1, N2b) se aplicaron dos paradigmas, tipo odball, uno con sonidos tonales y el otro, con estímulos consonántico-vocales (CV). 
Resultados: En comparación con las personas sanas, la persona con disnomia tenía una amplitud del habla reducida. El análisis de desviación de la forma del potencial de la norma mostró una morfología N2b incorrecta en caso del estímulo del habla, lo cual puede estar relacionado con la falta de representación fonológica.

Conclusiones: En el caso presentado, a los 6 años de la ictus, la actividad cerebral neurofisiológica en el campo del procesamiento de la representación fonológica no volvió del todo al estado primitivo. Los potenciales MMN y N2b con un instrumento de evaluación muy sensible de los daños de procesamiento auditivo y pueden ser medidas con falta de concentración de la atención y sin necesidad de realizar ninguna tarea, estos rasgos son particularmente útiles en los exámenes de personas con afasia.

Palabras clave: potencial de disparidad $(\mathrm{MMN}) \bullet \mathrm{N} 2 \mathrm{~b} \bullet$ disnomia $\bullet$ procesamiento auditivo

\title{
ВОЛНА НЕСООТВЕТСТВИЯ И КОМПОНЕНТА N2В, ВЫЗВАННАЯ ТОНАЛЬНЫМИ ЗВУКАМИ У ЛЮДЕЙ С ДИСНОМИЕЙ: КЕЙС-СТАДИ
}

\section{Изложение}

Введение: Выяснение часто наблюдаемых в случае афазии нарушенией слуховой обработки производится путем использования вызванных потенциалов (ERP) - метода, который позволяет следить мозговые процессы при высоком временном разрешении. Волна несоответствия (MMN) и амплитуда компонента N2b отражают аспекты звукоподражательной памяти, концентрации внимания и фонологической репрезентации. В настоящей работе оценивалась слуховая обработка речи и тональные звуки у людей с дисномией спустя 6 лет после инсульта и искался ответ на вопрос, могут ли вызванные потенциалы помочь найти возможные нейропсихологические последствия после выздоровления или реабилитации.

Материал и методы: Результаты человека с дисномией, который 6 лет назад перенес инсульт, а затем прошел терапию, сравнивались с результатами 6 здоровых людей. Для получения вызванных потенциалов (MMN, N1, $\mathrm{N} 2 \mathrm{~b})$ были использованы две парадигмы типа oddball, одна с использованием тональных звуков, а другая - консонантно-сонантных импульсов $(\mathrm{CV})$.

Результаты: В сравнении со здоровыми людьми, у человека с дисномией была пониженная амплитуда МMN в центральных передних локализациях электродов, особенно для импульса речи. Анализ отклонения формы волны от нормы показал неправильную морфологию N2b в случае импульса речи, что может быть связано с отсутствием фонологической репрезентации.

Итоги: В представленном случае, спустя 6 лет после инсульта, не было полного возврата к прежнему состоянию нейрофизиологической активности мозга в области обработки фонологических репрезентаций. Потенциалы MMN i N2b - это очень чувствительный инструмент оценки повреждений слуховой обработки и ини могут измеряться при нарушении концентрации внимания и без необходимости исполнения каких-либо заданий - эти качества являются особенно полезными при исследованиях людей с афазией.

Ключевые слова: волна несоответствия $(\mathrm{MMN}) \cdot \mathrm{N} 2 \mathrm{~b} ・$ дисномия • слуховая обработка

\section{FALA NIEZGODNOŚCI I KOMPONENTA N2B WYWOŁANE PRZEZ DŹWIĘKI TONALNE I MOWĘ U OSÓB Z DYSNOMIĄ: STUDIUM PRZYPADKU}

\begin{abstract}
Streszczenie
Wprowadzenie: Wyjaśnienie często zaobserwowanych w przypadku afazji zaburzeń przetwarzania słuchowego odbywa się poprzez użycie potencjałów wywołanych (ERP) - metody, która pozwala na obserwowanie procesów mózgowych przy wysokiej rozdzielczości czasowej. Fala niezgodności (MMN) i amplituda komponenty N2b odzwierciedlają aspekty pamięci dźwiękonaśladowczej, skupienia uwagi oraz reprezentacji fonologicznej. W niniejszej pracy oceniano słuchowe przetwarzanie mowy i dźwięków tonalnych u osoby z dysnomią 6 lat po udarze mózgu i szukano odpowiedzi na pytanie czy potencjały wywołane mogą pomóc w znalezieniu możliwych konsekwencji neurofizjologicznych po wyzdrowieniu lub rehabilitacji.
\end{abstract}

Materiał i metody: Wyniki osoby z dysnomią, która 6 lat temu miała udar mózgu, a następnie przeszła terapię były porównywane z wynikami 6 zdrowych osób. Do uzyskania potencjałów wywołanych (MMN, N1, N2b) zastosowano dwa paradygmaty typu oddball, jeden z użyciem dźwięków tonalnych, a drugi - bodźców spółgłoskowo-samogłoskowych (CV). 
Wyniki: W porównaniu z osobami zdrowymi, osoba z dysnomią mała obniżoną amplitudę MMN w środkowoprzednich lokalizacjach elektrod, szczególnie dla bodźca mowy. Analiza odchylenia kształtu fali od normy wykazała niepoprawną morfologię N2b w przypadku bodźca mowy, co może wiązać się z brakiem reprezentacji fonologicznej.

Wnioski: W przedstawionym przypadku, 6 lat po odbytym udarze, neurofizjologiczna aktywność mózgu w zakresie przetwarzania reprezentacji fonologicznych nie wróciła w pełni do poprzedniego stanu. Potencjały MMN i N2b są bardzo czułym narzędziem oceny uszkodzeń przetwarzania słuchowego i mogą być mierzone przy braku skupienia uwagi i bez potrzeby wykonywania jakichkolwiek zadan - te cechy są szczególnie przydatne przy badaniach osób z afazją.

Słowa kluczowe: fala niezgodności $(\mathrm{MMN}) \bullet \mathrm{N} 2 \mathrm{~b} \bullet$ dysnomia $\bullet$ przetwarzanie słuchowe

\section{Background}

Aphasia is an acquired communication disorder caused by a focal brain lesion, typically vascular damage from a stroke in the language-dominant cerebral hemisphere [1,2]. It is characterized by multimodal language impairment which may include speaking, understanding, reading, and writing $[3,4]$. Here we use the Boston Classification System [5], commonly used in clinical practice to classify disorders according to a patient's comprehension, fluency, naming, and repetition abilities. BCS includes Broca’s aphasia, transcortical motor aphasia, conduction aphasia, anomic aphasia, Wernicke's aphasia, transcortical sensory aphasia, transcortical mixed aphasia, and global aphasia. In anomic aphasia, the lesion is often in the temporoparietal area and naming or word-finding problems are major features [5].

There are several studies of recovery in aphasic patients, especially using neuroimaging methods [6-9]. Although these techniques have high space resolution in locating the damaged area and on finding the loci of activated areas, they have a poor time resolution. This might be a limitation if a clinician wants to assess neuronal processes or time-locked brain activities which require high temporal resolution, such as perception, attention, or echoic memory traces [10-12]. Electrophysiological methods, such as event-related potentials (ERPs), are a non-invasive technique that can be used to investigate temporal aspects of auditory discrimination using verbal and non-verbal stimuli, especially in cases having abnormal language function $[13,14]$. Although ERPs have been used to investigate language processes since the 1980s [14-17], its clinical application in aphasic patients has been minimal.

Few studies have used ERPs to investigate the correlation between different types of aphasia and different types of lesions, and how they change over time; in such a way, ERPs can provide a better understanding of the underlying processing and the reorganization involved in recovery, which can be used as a recovery index. However, most of the studies have focused on deficits in language production and there is only a sparse literature on auditory receptive processing and phonological loops between language and working memory $[18,19]$. From the point of view of clinical research and applications, this area is particularly significant.

In this paper we elicited the mismatch negativity (MMN) $[20,21]$ a change-specific component of the ERP which is considered to represent brain processes that form the biological substrate of central auditory perception, memory, and attention, using a post-rehabilitation case study of anomic aphasia. The classical MMN is a fronto-centrally $(\mathrm{Fpz}, \mathrm{Fz}$, and $\mathrm{Cz})$ negative component of the auditory event-related potentials (AERPs), usually peaking at 100$250 \mathrm{~ms}$ from stimulus onset and positive at the mastoids. Its generators are mainly in the bilateral supratemporal cortices, with contributions from the frontal lobes, right parietal lobe [21-24], thalamus, and hippocampus (based on animal studies [24-28]). Currently, the MMN provides an objective measure of auditory perception and discrimination reflecting short-term memory (sensory memory) and of echoic memory; the latter represents a repetitive aspect of ongoing stimulation before a deviant event comes along, whereupon it fades within 5-10 s [23,29-31].

Although such a memory-based model is widely accepted, there are different views concerning MMN generation and interpretation (examples are the adaptation model and the predictive model) [for a short overview see 32,33]. After the incoming stimulus is detected, additional cognitive processes are required for classifying and categorizing it. For speech stimuli, the N2b subcomponent is particularly important for the study of phonological activation processes $[34,35]$. The N2b component seems particularly important when considering Pulvermüller's work which proposes that cell assemblies are organized in perisylvian cortices in order to recognize phonological word forms and create memory traces [36-38].

Using auditory oddball paradigms it has been shown that the MMN (elicited by frequency and duration changes) is attenuated in amplitude in patients with a left-hemispheric stroke [14,40-42]. Furthermore, Ilvonen and colleagues [43] followed the recovery of eight left-hemisphere stroke patients: in the first 10 days the MMNs were quite small in amplitude for both duration and frequency changes; however, they became progressively larger, reaching normal amplitudes between 3 to 6 months after stroke, and with an improvement in speech-comprehension during the follow-up period. There are also some studies that elicited MMN with oddball speech sounds (synthesized vowels, syllables, or consonant-vowels), with a consistent pattern of MMN attenuation or absence $[10,14,44,45]$.

The same question remains, however. In aphasia, which is impaired: language production or the perception of the acoustic features of speech? The main problem in answering this question is the difficulty in gathering a homogenous experimental group, both in terms of type of aphasia and specific language function. Furthermore, what can electrophysiological measures, namely MMN and its underlying components, tell us from successful post-rehabilitation cases? Compared to normal subjects, how do the 
AERP components of an aphasic subject differ after their brain function has recovered?

We present a case study of an anomic aphasic subject after a successful post-stroke rehabilitation (successful from a cognitive and behavioral point of view). Our aim is to evaluate, using MMN and N2b, the automatic auditory receptive processing of speech and non-speech stimuli in a type of aphasia that produces deficits mainly in language production. In addition, we compare the MMN and N2b wave morphology using the classification of Zheng et al. [46], leading to a possible recovery index. The index might have clinical relevance as a measure of how neuronal responses associated with sound change detection are progressing.

\section{Methods and procedures}

We present a case study of a woman (age 46, with 12 years of Portuguese education) who 6 years ago had a left-hemisphere stroke involving the left middle cerebral artery. Shortly after the stroke she had Broca's aphasia with stereotypical hemiparesis and hemihypoesthesis (a reduction in sensitivity on the right side of the body), symptoms that can be due to damage to the thalamocortical fibers in the posterior limb of the internal capsule. She did speech and language therapy and evolved to an anomic aphasia. Currently, she presents a right hemihypoesthesis and an anomic aphasia (naming of 11/16; auditory comprehension 8/8; repetition 27/30; level of fluency 4/5) [47]. She has made an excellent functional recovery with only a slight naming difficulty remaining, with an aphasia coefficient of $85 \%$ based on the Lisbon aphasia examination battery, which means a mild severity of aphasia. She has normal vision and hearing and a right-handedness laterality index of $85 \%$ corresponding to the $6^{\text {th }}$ right decile [48].

There are different results between authors for MMN amplitude and latency, even when using the same or similar auditory oddball paradigms; normative data is also scarce. In order to make comparisons, six control subjects, all women, were selected for the study (mean age $=30.6 \pm 5.12$ years; mean length of Portuguese education $=14 \pm 2$ years). All subjects were Portuguese native speakers, had normal hearing and normal or corrected-to-normal vision, and a mean right-handedness laterality index of $85.9 \%$, corresponding to the $6^{\text {th }}$ right decile [48]. They all gave written consent, after the nature and objective of the experiment was explained to them. Institutional ethical clearance was obtained.

During the electroencephalographic (EEG) recording, participants were binaurally presented with two auditory oddball stimulation sequences of one block of pure tone (300 trials) and one block (300 trials) of consonant-vowel (CV) stimuli, each containing a stimulus onset asynchrony (SOA) of $800 \mathrm{~ms}$ and a proximal sound level of $75 \mathrm{~dB}$ SPL. In the pure-tone blocks, the standard stimulus was a pure tone of $1000 \mathrm{~Hz}(100 \mathrm{~ms}$ duration, including rise and fall time of $10 \mathrm{~ms}$ ) replaced by a frequency deviant of $1100 \mathrm{~Hz}$ (same duration). Speech-stimuli blocks consisted of digitized (at $44.1 \mathrm{kHz}$ ) CV syllables of $175 \mathrm{~ms}$ duration spoken by a male native Portuguese voice. The standard phoneme was /ba/ and the deviant $/ \mathrm{pa} /$. These phonemes were selected due to the same place of articulation but different voicing, thus differing in the frequency domain $[49,50]$. In all single blocks, standard stimuli comprised $80 \%$ of all trials (240), while the deviant stimuli comprised $20 \%$ (60 trials). Stimuli were presented using ASA software v4.0.6.8 (ANT, Neuronic S.A.) via closed headphones while the participants where comfortably seated in an armchair and instructed to keep alert with eyes open, to actively listen to the auditory stimuli, and to focus on a small cross in the center of a computer screen during recording. Each individual data collection took about 40 minutes.

\section{EEG recording and data analysis}

EEGs were recorded using a bio-amplifier recording device Refa32 (ANT, Neuronic S.A.). Recordings were obtained from the following cup-shaped silver chloride (Ag$\mathrm{AgCl}$ ) electrodes: $\mathrm{Cz}, \mathrm{Fz}, \mathrm{Fpz}, \mathrm{M} 1, \mathrm{M} 2$, and $\mathrm{Oz}$ (ground). Electrodes were referenced to averaged ear lobes (A1 and A2). Impedance between the electrodes and skin did not exceed $10 \mathrm{k} \Omega$. The quality of recordings was monitored during data acquisition and continuous EEG data were stored on a computer hard disk for off-line analysis and grand averaging. An electrode was attached above the right eye to monitor the electrooculogram (EOG). Sweeps with amplitudes exceeding $\pm 70 \mu \mathrm{V}$ in any channel except EOG were excluded. Trials with blinks, saccades, or components that could be attributed to such artifacts (based on their topography and time course) were eliminated from the data for each subject before averaging [51]. The sampling rate was $512 \mathrm{~Hz}$ for each channel and the recording bandwidth was 0.05 to $100 \mathrm{~Hz}$. Offline processing included band-pass filtering [0.3-30 Hz], linear detrending, and a baseline correction (200 ms prior to stimulus onset, considering stimulus duration).

The first 10 sweeps of each epoch file were excluded from the averaging process to reduce ERP variation associated with the start of the stimulation sequence $[14,52]$. The MMN was determined from the $\mathrm{Fz}, \mathrm{Cz}$, and $\mathrm{Fpz}$ electrodes and measured by separately computing difference waves obtained by subtracting the average standard-stimulus response from the average deviant-stimulus response for each electrode and subject [53]. The mean amplitude analysis (that is, the mean voltage over the $50 \mathrm{~ms}$ period time window) was centered at the latency of largest negative peak for $\mathrm{Fz}, \mathrm{Cz}$, and $\mathrm{Fpz}$ and positive for mastoids, occurring between 100 and $250 \mathrm{~ms}$.

\section{Results}

The difference waveforms derived from the pure-tone and speech CV paradigms for the control and the anomic aphasia subject are shown in Figure 1. Table 1 gives an overview of the MMN latency and amplitude results. Cohen's effect sizes were obtained with a nonparametric MannWhitney test $z$-value. The grand averages for the deviant waveforms from the CV paradigm are shown in Figure 2.

The largest mean MMN amplitude for the control group was found over $\mathrm{Cz}$ (mean $=-5.19 \mu \mathrm{V} ; \mathrm{SD}=1.6)$ with a mean latency of $215 \mathrm{~ms}(\mathrm{SD}=31.2)$ for speech stimuli. For the aphasic subject, the largest MMN amplitude was also for speech stimuli and over $\mathrm{Cz}(-2.28 \mu \mathrm{V})$ with a latency of $168 \mathrm{~ms}$. 
Pure tones
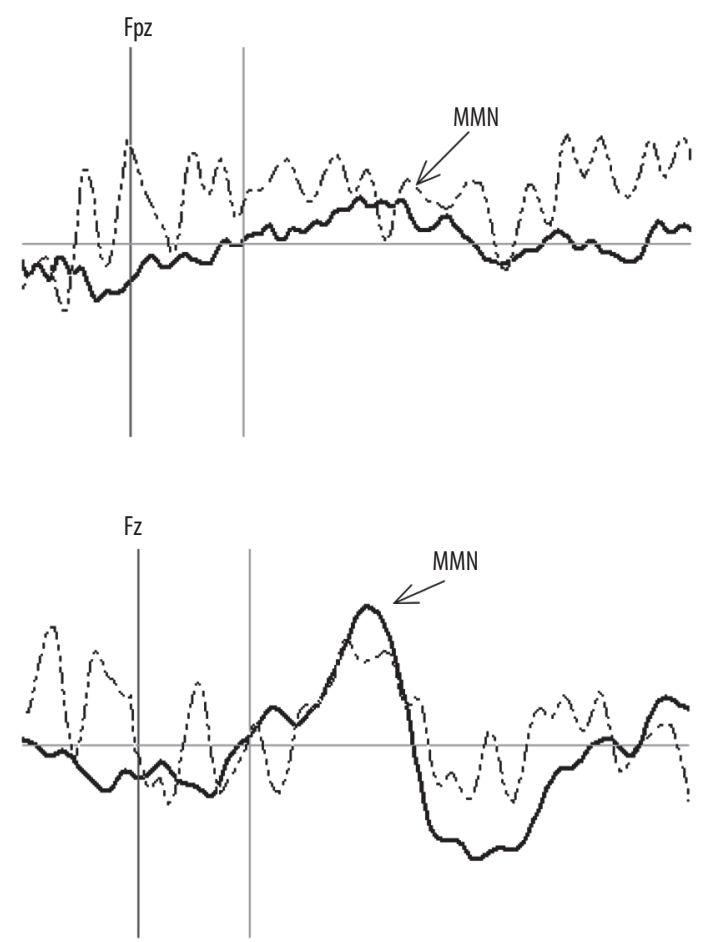

Cz
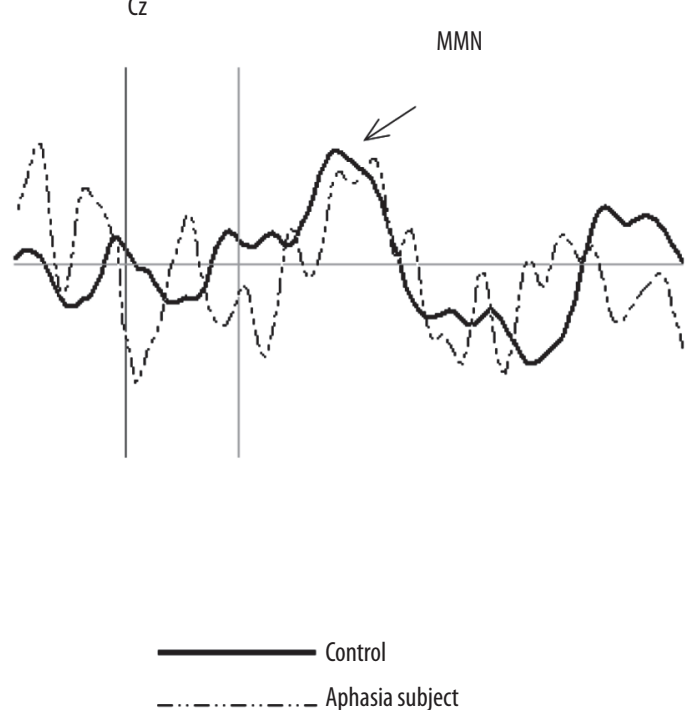

CV
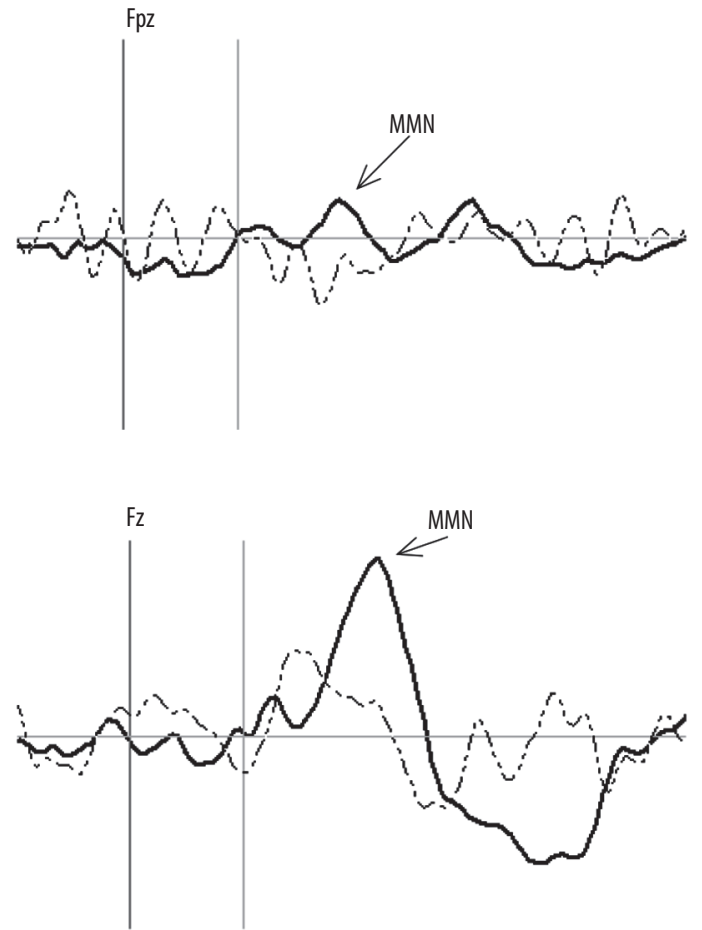

$\mathrm{Cz}$
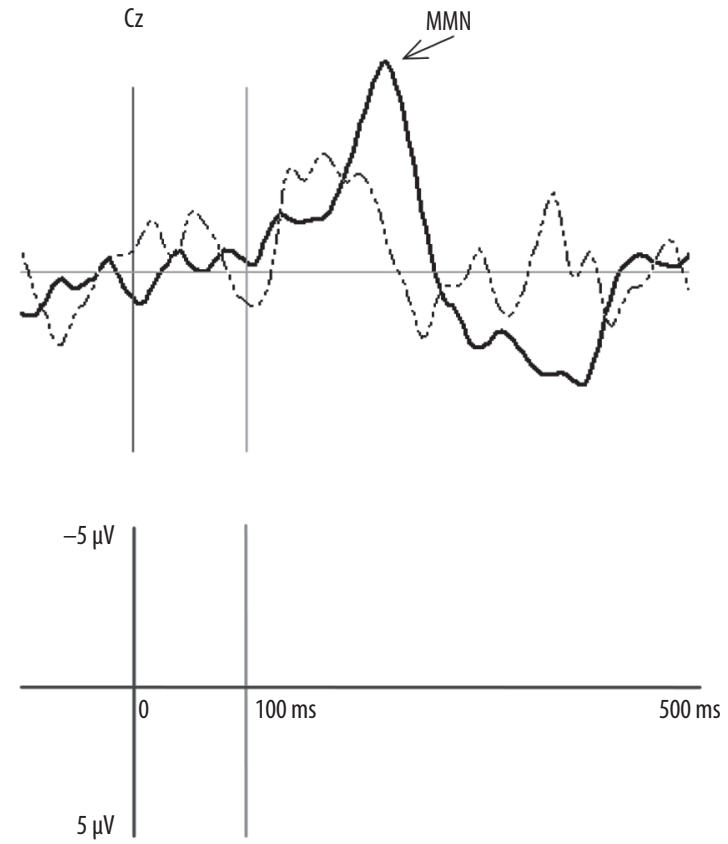

Figure 1. Grand average MMN difference waveforms (deviant minus standard) for pure tones and consonant-vowel (CV) paradigms for the anomic aphasia subject (dashed line) and the control group (solid line) 
Table 1. Mean amplitude and peak latencies of the MMN wave in Fpz, Fz, and Cz, for the AA subject and the comparison group

\begin{tabular}{ccccc}
\hline & \multicolumn{2}{c}{ AA subject } & \multicolumn{2}{c}{ Control group (mean/SD) } \\
\cline { 2 - 5 } & $\begin{array}{c}\text { Tone } \mathbf{M M N} \\
\boldsymbol{\mu V} / \mathbf{m s}\end{array}$ & $\begin{array}{c}\text { Speech } \mathbf{M M N} \\
\boldsymbol{\mu V} / \mathbf{m s}\end{array}$ & $\begin{array}{c}\text { Tone } \mathbf{M M N} \\
\boldsymbol{\mu V} / \mathbf{m s}\end{array}$ & $\begin{array}{c}\text { Speech } \mathbf{M M N} \\
\boldsymbol{\mu V} / \mathbf{m s}\end{array}$ \\
\hline $\mathrm{Fpz}$ & $-1.62 / 170$ & $---1.35(0.7) / 223(46.1)$ & $-1.59^{*}(0.5) / 226(43.6)$ \\
\hline $\mathrm{Fz}$ & $-2.05 / 199$ & $-1.85 / 148$ & $-3.68^{*}(1.1) / 219(18.4)$ & $-5.08^{*}(1.7) / 223(32.2)$ \\
\hline $\mathrm{Cz}$ & $-1.98 / 199$ & $-2.28 / 168$ & $-3.78(1.1) / 188(24.8)$ & $-5.19^{*}(1.6) / 215(31.2)$ \\
\hline
\end{tabular}

AA - anomic aphasia; control group $(n=5) ; \mu \mathrm{V}$ - microvolts (amplitude); ms - milliseconds (latency); ${ }^{*}$ large effect size [54], $r>0.65$ (>double absolute value); “---" - absent
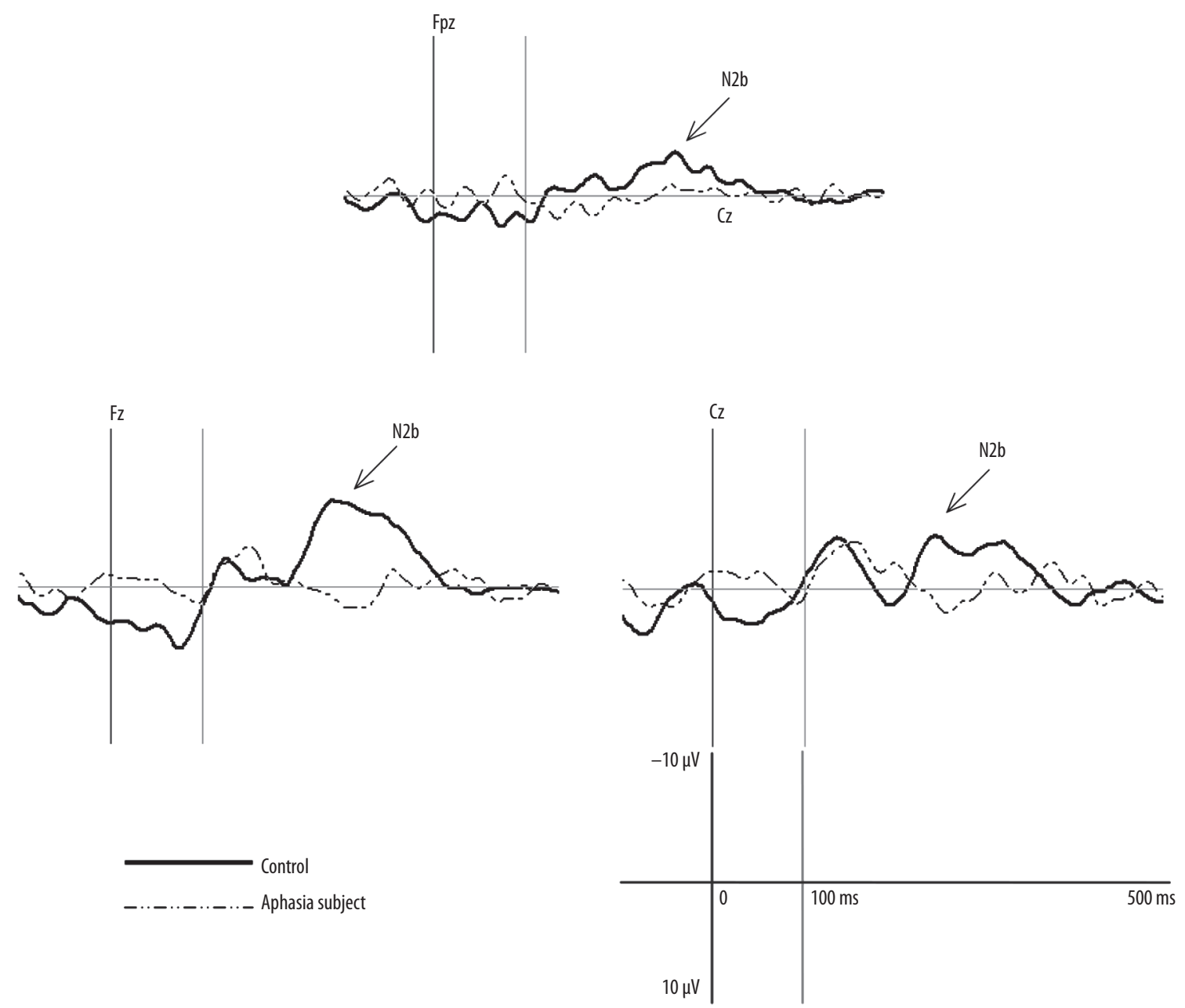

Figure 2. Grand average deviant waveforms for consonant-vowel (CV) paradigm for the anomic aphasia subject (dashed line) and the control group (solid line)

In both conditions the control group had larger MMN amplitudes, particularly at $\mathrm{Fz}$, achieving twice the amplitude of the aphasia subject with a large effect size [54]. For all subjects, speech stimuli elicited an enhanced MMN comparable to that from pure tones; however the aphasic subject revealed a slightly earlier MMN for speech stimuli at $\mathrm{Fz}, \mathrm{Cz}$, and absent at Fpz.
For control subjects, the MMN waveform morphology was of a similar pattern across frontocentral electrode sites for the pure-tone and speech conditions. The aphasic subject revealed a poor-moderately defined waveform, according to the work of Zheng et al. [46]. Furthermore, the average deviant waveform for the consonant-vowel paradigm was poorly defined in the aphasic subject, mainly the N2b component. 


\section{Discussion}

Case studies are criticized because the data collected cannot necessarily be generalised to the wider population, and because it is also very difficult to conclude a definite cause/ effect. The presented case study was conducted to provide deeper design and more detailed analysis, and thus may be useful for stimulating further ideas and producing novel hypotheses which can be later tested.

The results of this case study suggest that the aphasic subject had a MMN to pure-tone and speech stimuli, although with a poor-moderately defined waveform according to the morphology classification of Zheng et al. [46]. Thus, with smaller amplitudes in $\mathrm{Fz}, \mathrm{Cz}$, and absent in $\mathrm{Fpz}$ compared to controls, this finding supports the literature which points to $\mathrm{MMN}$ as reflecting automatic processing of acoustic-phonetic input $[17,20,39]$, possibly related to a low accuracy of behavioral discrimination of sound change $[10,55]$ and phonological analysis $[31,56]$.

Interestingly, our aphasic subject showed an earlier MMN under CV conditions, and this seems to be related to ERP subcomponents. Keeping in mind that shortly after her stroke the patient had Broca's aphasia, Bird et al. [57] have indicated that this type of aphasia may also reflect a deficit in phonological processing. More specifically, the analysis of the elicited deviant waveform revealed an absence of $\mathrm{N} 2 \mathrm{~b}$ or perhaps a fusion with $\mathrm{N} 1$ that was also diminished, which resulted in an early MMN compared to controls. A difference in age between the aphasic participant and the control group did not bias the results considering the recent published $\mathrm{N} 2$ normative data [58]. In addition, $\mathrm{N} 1$ is suggested to reflect integrative processing of acoustic features of the incoming stream of speech [59], but not a neurological representation of phonemes. Any deviance to this stream will be detected by automatic attention mechanisms being indexed by N2b $[41,60]$. In addition, Gow and Caplan [61] reported that phoneme discrimination used to investigate acoustic-phonetic processing always requires close attention. Our results support the findings of Pettigrew et al. $[14,17]$ in that aphasic subjects may demonstrate deficits in lexical processing at the attentional level due to a previously impaired phonological analysis. Interestingly, similar to Becker \& Reinvang [34], we observed a reduced $\mathrm{N} 1$ in responses to both pure tones and CVs, but no similar results concerning $\mathrm{N} 2 \mathrm{~b}$ reduction, even with both active auditory oddball paradigms. A possible explanation might be that we are presenting one single case study, or $\mathrm{N} 2 \mathrm{~b}$ reduction to speech stimuli may be specifically related to anomia, because none of the aphasic subjects from the study of Becker \& Reinvang [34] were of the anomic aphasia type or had anomia as a neuropsychological deficit. If so, N2b could represent the neurobiological substrate for the activation of phonological representation and categorization of speech elements, with this attentional trigger activation indexed by frontal MMN. However, only future studies with anomic subjects can confirm this hypothesis.

These amplitude reductions might be related to underlying neuronal damage sequelae - in our case, this damage probably derives from thalamocortical fibers in the posterior limb of the internal capsule, as revealed from the remaining hemihypoesthesis.
Hurley et al. [62] demonstrated a correlation between atrophy in posterior temporal areas and diminished N400 mismatch potentials as a possible mechanism for anomia in subjects with primary progressive aphasia. In our case, the lesion was a left-hemisphere stroke, involving the left middle cerebral artery (known to emerge from the lateral sulcus supplying frontal, temporal, and parietal areas). Considering the cell assembly model theory (for review see $[17,36,63])$, the perisylvian cortical neurons that process word forms would be affected or damaged. Therefore, neurons left unaffected by the lesion will reflect an attenuated MMN response and poorly defined ERP components in the average deviant waveform, mainly N2b. Furthermore, Pulvermüller [64] has proposed an "ignition threshold" for the assembly neurons, and that non-activation is related to lesion severity. Therefore, the highly reduced $\mathrm{N} 2 \mathrm{~b}$ in our case might be related to a low ignition threshold, resulting in weak internal connections between phonological and semantic information and giving rise to the subject's naming difficulties. This seems to be consistent with new findings on perisylvian language networks [64-66] and the role of the arcuate fasciculus [67].

Finally, it is still not known what type of neurons or layers generate $\mathrm{MMN}$, although it seems to follow the vertical functional organization of the neocortex. However, it is known that MMN may reflect damage severity and so tracks the recovery of sound discrimination and the alleviation of aphasia after cortical stroke [43]. Thus, MMN may provide a promising tool in clinical practice for evaluating and monitoring the recovery of auditory discrimination $[21,68]$.

Several authors have already pointed to $\mathrm{MMN}$ as a recovery index. However, this discussion highlights the importance of using pure-tone and speech stimuli, as well as the analysis of $\mathrm{N} 1$ and $\mathrm{N} 2$ components in the average deviant waveform under different conditions. In particular, N2b seems to indicate a very early initial difference between speech and non-speech sound processing and reflects processes of transient arousal triggered by unattended discrimination processes. Further experimental group studies, with different types of aphasia, may confirm the hypothesis.

\section{Conclusions}

In cases of sudden onset brain damage, cognitive and perceptual deficits are initially quite severe. In stroke and other brain-injured patients it is important to determine the damage to neural networks involved in sound and speech perception soon after the damage occurs in order to monitor spontaneous recovery and to delineate possible recommendations for therapy. Unfortunately, such patients are often unable to cooperate or to understand instructions. The MMN can be registered in the absence of conscious attention and has no task requirements. From the point of view of clinical research and applications, this is significant, and it makes the MMN particularly suitable for monitoring aphasic subjects and predicting language recovery.

ERP components such as $\mathrm{N} 1, \mathrm{~N} 2 \mathrm{~b}$, and $\mathrm{MMN}$ seem to have high sensitivity in detecting acoustic-phonetic processing and phonological analysis deficits in aphasic patients, either during the acute stage, after spontaneous recovery, or 
following therapy. Further, these deficits seemed to be better highlighted by a speech stimuli paradigm rather than by a non-speech paradigm, as seen in the MMN tone vs. speech results (Table 1).

The evaluation of the effectiveness of training and rehabilitation programs also highlights the importance of using the MMN as a recovery index, with expected amplitude growth after therapy sessions. However, longitudinal studies are still required. The results of this case study indicate that even 6 years after a stroke, neurophysiologic brain activity had not fully recovered. MMN seems to be a sensitive tool for detecting functional brain sequelae, especially using speech stimuli. Furthermore, it seems that $\mathrm{N} 2 \mathrm{~b}$ might be related to anomia, thus indexing cell assembly disruption and impaired activation of phonological representation processes which are the basis of this neuropsychological deficit, although further studies are required. The analysis of pre-attentive separate components (N1, N2b, and MMN) might increase the reliability and specificity of ERP measures as applied to clinical practice in aphasiology.

\section{References:}

1. Damasio AR. Signs of aphasia. In: Taylor M (eds.). Acquired aphasia. New York: Academic Press, 1998; 25-41.

2. Darley FL (ed.). Aphasia. Philadelphia: WB Saunders, 1982.

3. Goodglass H (ed.). Understanding aphasia. San Diego: Academic Press, 1993.

4. Hallowell B, Chapey R. Introduction to language intervention strategies in adult aphasia. In: Chapey R (ed.). Language intervention strategies in aphaisa and neurogenic communication disorders $\left(5^{\text {th }}\right.$ ed.). New York: Lippincott Williams \& Wilkins, 2008.

5. Goodglass H, Kaplan E (eds.). The assessment of aphasia and related disorders. Lea \& Febiger, Philadelphia, $2^{\text {nd }}$ ed., 1983.

6. Crinion J, Holland A, Copland D, Thompson CK, Hillis AE. Quantifying brain lesions in neuroimaging research examining language recovery after stroke. NeuroImage, 2013; 73: 208-14

7. Thompson CK, den Ouden D-B. Neuroimaging and recovery of language in aphasia. Curr Neurol Neurosci Rep, 2008; 8(6): 475-83

8. Rapp B, Caplan D, Edwards S, Visch-Brink E, Thompson CK. Neuroimaging in aphasia treatment research: issues of experimental design for relating cognitive to neural changes. Neuroimage, 2013; 73: 200-7

9. Meinzer M, Harnish S, Condway T, Crosson B. Recent developments in functional and structural imaging of aphasia recovery after stroke. Aphasiology, 2011; 25(3): 271-90.

10. Ilvonen T-M, Kujala T, Kozou H, Kiesiläinen A, Salonen O, Alku P et al. The processing of speech and non-speech sounds in aphasic patients as reflected by the mismatch negativity (MMN). Neurosci Lett, 2004; 366: 235-40.

11. Tomé $\mathrm{D}$, Marques-Teixeira J, Barbosa F. Temporal lobe epilepsy in childhood: a study model of auditory processing. J Neurol Neurophysiol, 2012; 3(2).

12. Zatorre R, Evans A, Meyer E, Gjedde A. Lateralization of phonetic and pitch discrimination in speech processing. Science, 1992; 256: 846-9.

13. Hough MS, Downs CR, Cranford J, Givens G. Measures of auditory processing in aphasia: behavioural and electrophysiological analysis. Aphasiology, 2003; 17(2): 159-72.

14. Pettigrew CM, Murdoch BE, Kei J, Ponton C, Alku P, Chenery HJ. The mismatch negativity (MMN) response to complex tones and spoken words in individuals with aphasia. Aphasiology, 2005; 19(2): 131-63.

15. Friederici AD, Pfeifer E, Hanhe A. Event-related brain potentials during natural speech processing: Effects of semantic, morphological, and syntactic violations. Cogn Brain Res, 1993; 1: 183-92.

16. Kutas M, Hillyard, SA. Reading senseless sentences: brain potentials reflect semantic incongruity. Science, 1980; 207: 203-5.
17. Pettigrew CM, Murdoch BE, Chenery HJ, Kei J. The relationship between the mismatch negativity (MMN) and psycholinguistic models of spoken word processing. Aphasiology, 2004; 18(1): 3-28.

18. Baddeley A. The episodic buffer: a new component of working memory? Trends Cogn Sci, 2000; 4: 417-23.

19. Jääskeläinen IP (ed.). Introduction to cognitive neuroscience. Ventus Publishing ApS, 2012; 92-112.

20. Näätänen R. The mismatch negativity: a powerful tool for $\operatorname{cog}$ nitive neuroscience. Ear Hearing, 1995; 16: 6-18.

21. Näätänen R, Paavilainen $\mathrm{P}$, Rinne $\mathrm{T}$, Alho $\mathrm{K}$. The mismatch negativity (MMN) in basic research of central auditory processing: a review. Clin Neurophysiol, 2007; 118: 2544-90.

22. Näätänen R. Selective attention and evoked potentials in humans: a critical review. Biol Psychol, 1975; 2: 237-307.

23. Näätänen R. The perception of speech sounds by the human brain as reflected by the mismatch negativity (MMN) and its magnetic equivalent (MMNm). J Psychophysiol, 2001; 38: 1-21.

24. Kraus N, McGee T, Carrell T, King C, Littman T, Nicol T. Discrimination of speech-like contrasts in the auditory thalamus and cortex. J Acoust Soc Am, 1994; 96: 2758-68.

25. Kraus N, McGee T, Littman T, Nicol T, King C. Non-primary auditory thalamic representation of acoustic change. J Neurophysiol, 1994; 72: 1270-77.

26. Csépe V, Karmos G, Molnár M. Subcortical evoked potential correlates of early information processing: mismatch negativity in cats. In: Basar E, Bullock TH (eds.), Springer series in brain dynamics 2. Berlin: Springer Verlag, 1989; 279-89.

27. Astikainen P, Ruusuvirta T, Korhonen T. Longer storage of auditory than visual information in the rabbit brain: evidence from the dorsal hippocampal electrophysiology. Exp Brain Res, 2005; 160(2): 189-93.

28. Ruusuvirta T, Korhonen T, Penttonen M, Arikoski J, Kivirikko K. Hippocampal evoked potentials to pitch deviances in an auditory oddball situation in the cat: Experiment I. Int J Psychophysiol, 1995; 20: 33-9.

29. Hari R, Hämäläinen M, Ilmoniemi R, Kaukoranta E, Reinikainen $\mathrm{K}$, Salminen J et al. Responses of the primary auditory cortex to pitch changes in a sequence of tone pips: neuromagnetic recordings in man. Neurosci Lett, 1984; 50: 127-32.

30. Näätänen R, Paavilainen P, Alho K, Reinikainen K, Sams M. The mismatch negativity to intensity changes in an auditory stimulus sequence. Electroencephalogr Clin Neurophysiol, 1987; Suppl 40: 125-31.

31. Näätänen R, Alho K. Mismatch negativity: the measure for central sound representation accuracy. Audiol Neuro-Otol, 1997; 2: 341-53.

32. Winkler I. Interpreting the mismatch negativity. J Psychophysiol, 2007; 21(3-4): 147-63. 
33. May P, Tiitinen H. Mismatch negativity (MMN), the devianceelicited auditory deflection, explained. J Psychophysiol, 2010; 47: 66-122.

34. Becker F, Reinvang I. Identification of target tones and speech sounds studied with event-related potentials: Language-related changes in aphasia. Aphasiology, 2012; iFirst: 1-21.

35. Patel SH, Azzam PN. Characterization of N200 and P300: selected studies of the event-related potential. Int J Med Scienc, 2005; 2: 147-54.

36. Pulvermüller F. Hebb's concept of cell assemblies and the psychophysiology of word processing. Psychophysiol, 1996; 33: 317-33.

37. Pulvermüller F, Kujala T, Shtyrov Y, Simola J, Tiitinen H, Alku $\mathrm{P}$ et al. Memory traces for words as revealed by the mismatch negativity. Neuroimage, 2001; 14: 607-16.

38. Pulvermüller F, Schumann JH. Neurobiological mechanisms of language acquisition. Lang Learn, 1994; 44: 681-734.

39. Aaltonen O, Tuomainen J, Laine M, Niemi P. Cortical differences in tonal versus vowel processing as revealed by an ERP component called mismatch negativity. Brain Lang, 1993; 44: 139-52.

40. Auther L, Wertz R, Miller T, Kirshner H. Relationships among the mismatch negativity (MMN) response, auditory comprehension, and site of lesion in aphasic adults. Aphasiology, 2000; 14: 461-70.

41. Becker F, Reinvang I. Mismatch negativity elicited by tones and speech sounds: changed topographical distribution in aphasia. Brain Lang, 2007; 100: 69-78.

42. Ilvonen T-M, Kujala T, Tervaniemi M, Salonen O, Näätänen R, Pekkonen E. The processing of sound duration after left hemisphere stroke: event-related potential and behavioral evidence. Psychophysiol, 2001; 38: 622-8.

43. Ilvonen T-M, Kujala T, Kiesiläinen A, Salonen O, Kozou H, Pekkonen E et al. Auditory discrimination after left hemisphere stroke: an MMN follow-up study. Stroke, 2003; 34: 1746-53.

44. Becker F, Reinvang I. Successful syllable detection in aphasia despite processing impairments as revealed by event-related potentials. Behav Brain Func, 2007; 3: 6.

45. Csépe V, Osman-Sági J, Molnár M, Gósy M. Impaired speech perception in aphasic patients: event-related potential and neurophysiological assessment. Neuropsychologia, 2001; 39: 1194-208.

46. Zheng Y, Zhao F, Liang M, Bardsley B, Yang H, Zhang Z. Toward an understanding of auditory evoked cortical event-related potentials: characteristics and classification. Audiol Med, 2011; 1-10.

47. Damasio AR. Perturbações neurológicas da linguagem e de outras funções simbólicas. Philosophy Doctor dissertation and thesis in Medicine. Lisboa: Faculdade de Medicina da Universidade de Lisboa, 1973.

48. Oldfield RC. The assessment and analysis of handedness: the Edinburgh inventory. Neuropsychologia, 1971; 9: 97-113.

49. Martin B, Sigal A, Kurtzberg D, Stapells D. The effects of decreased audibility produced by high-pass noise masking on cortical event-related potentials to speech sounds /ba/ and / da/. J Acoust Soc Am, 1997; 101: 1585-99.
50. Martin B, Kurtzberg D, Stapells D. The effects of decreased audibility produced by high-pass noise masking on N1 and the mismatch negativity to speech sounds /ba/ and /da/. J Speech Lang Hear Res., 1999; 42: 271-86.

51. Jung TP, Makeig S, Westerfield M, Townsend J, Courchesne E, Sejnowski TJ. Removal of eye activity artifacts from visual event-related potentials in normal and clinical subjects. Clin Neurophysiol, 2000; 111: 1745-58.

52. Pekkonen E, Rinne T, Näätänen R. Variability and replicability of the mismatch negativity. Electroencephalograph Clin Neurophysiol, 1995; 96: 546-54.

53. Duncan C, Barry R, Connolly J, Fischer C, Michie P, Näätänen $\mathrm{R}$ et al. Event-related potentials in clinical research: Guidelines for eliciting, recording, and quantifying mismatch negativity, P300, and N400. Clin Neurophysiol, 2009; 120: 1883-908.

54. Cohen J. A Power Primer. Psychol Bull, 1992; 112(1): 155-9.

55. Kujala T, Kallio J, Tervaniemi M, Näätänen R. The mismatch negativity as an index of temporal processing in audition. Clin Neurophysiol, 2001; 112: 1712-19.

56. Dehaene-Lambertz G. Electrophysiological correlates of categorical phoneme perception in adults. NeuroReport, 1997; 8(4): 919-24.

57. Bird H, Ralph MA, Seidenberg MS, McClelland, JL, Patterson K. Deficits in phonology and past-tense morphology: what's the connection? J Memory Lang, 2003; 48: 502-26.

58. Tomé D, Barbosa F, Nowak K, Marques-Teixeira, J. The development of the N1 and N2 components in auditory oddball paradigms: a systematic review with narrative analysis and suggested normative values. J Neural Transm, 2015; 122(3): 375-91.

59. Näätänen R, Winkler I. The concept of auditory stimulus representation in cognitive neuroscience. Psychol Bull, 1999; 125: 826-59.

60. Pritchard W, Shappell S, Brandt M. Psychophysiology of N200/ N400: a review and classification scheme. Adv Psychophysiol, 1991; 4: 43-106.

61. Gow JW, Caplan D. An examination of impaired acoustic-phonetic processing in aphasia. Brain Lang, 1996; 52: 386-407.

62. Hurley RS, Paller KA, Rogalski EJ, Mesulam MM. Neural mechanisms of object naming and word comprehension in primary progressive aphasia. J Neurosci, 2012; 32(14): 4848-55.

63. Garagnani M, Wennekers T, Pulvermüller F. A neuroanatomically-grounded Hebbian learning model of attention-language interactions in the human brain. Eur J Neurosci, 2008; 27(2): 492-513.

64. Pulvermüller F. Words in the brain's language. Behav Brain Sci, 1999; 22: 253-336

65. Catani M, Jones DK, Fytche DH. Perisylvian language networks of the human brain. Ann Neurol, 2005; 57: 8-16.

66. Wennekers T, Garagnani M, Pulvermüller F. Language models based on Hebbian cell assemblies. J Physiol (Paris), 2006; 100(1-3): 16-30.

67. Catani M, Mesulam M. The arcuate fasciculus and the disconnection theme in language and aphasia: history and current state. Cortex, 2008; 44: 953-61.

68. Näätänen R. Mismatch negativity: clinical research and possible applications. Int J Psychophysiology, 2003; 48: 179-88. 